\section{Impact of Environmental E ducation Classes at Missouri Botanical Garden on Attitude and Knowledge Change of Elementary School Children}

\author{
Anthony W. Kahtz
}

Additional index words. gardening classes, horticultural education

Summary. Two environmental education classes at Missouri Botanical Garden, "The Water Cycle: Making" a Terrarium" and "The Tropical Rainforest", were evaluated to determine their effects upon attitude and knowledge change of elementary school children. A pretestpost-test design was used to compare experimental and control groups. Data indicated that The Water Cycle: Making a Terrarium class had a positive influence on attitudes toward learning about plants and the environment the Tropical Rainforest class had no effect. Neither of the classes significantly affected the children's attitudes toward interacting with the environment. Both classes increased the knowledge base of participating children. There were no differences between male and female attitudes or knowledge in either class. Nonformal learning experiences of this type may be a more effective means of stimulating horticultural interest among young children than traditional classroom settings.

Department of Plant and Soil Science, Southern Illinois University, Carbondale, IL 62901

${ }^{1}$ Former graduate student. Currently a graduatc student in the Department of Horticulture at the University of Illinois at Urbana.

I thank the greater St.Louis public schools and the staff of the Missouri Botanical Garden for their interest and participation in this research. The cost of publishing this paper was defrayed in part by the payment of page charges. Under postal regulations, this paper therefore must be hereby marked advertisement solely to indicate this fact.
$T$ caching children about plants and the environment should be of concern to horticultural educators at all levels. Many attitudes are established, and are difficult to later change, by the time a student reaches high school (J aus, 1984; Linsky, 1971; Tourney and Tesconi, 1977). Researchers suggest that early exposure to environmental concepts may help children develop positive attitudes and a solid knowledge base with respect to the plant sciences. Elementary school children are thought to be incapable of complex abstract thought (-Booth et al.,1982; I nhelder, 1970; Matthai and Deaver, 1976; Smith and Nagel, 1972). Therefore, the use of sensory and hands on activities has proven to be an excellent didactic method.

Field trips to botanic gardens and similar institutions have great teaching potential, because they emphasize participatory activities (Danilov, 1976; Whittlin, 1970). Unlike in elementary school, where the primary goals are textbook learning and the acquisition of quantifiable skills, a public garden's main educational objective is to stimulate interest. A student's first exposure to public garden education often occurs when attending with their school group for a class or tour. In many cases, children are exposed to a single garden visit during their primary education (Pitman-Gelles, 1981). This limited exposure is disappointing, since field trips have been found to be the single most important factor in developing positive attitudes toward plants and the environment (Klepper, 1990).

Before 1991 enrollment in college level horticulture programs had dropped sharply during the previous decade (Couvillon, 1991), despite expanded efforts to recruit high school students (Gwynn and Thompson, 1990; J ackson, 1992). Of currently enrolled students in agriculture colleges, over fifty percent mention handson experiences when young as a major influence on their enrollment decision (Christmas, 1990). It is clear that nonformal teaching methods, emphasizing participatory activities, must become a more heavily utilized component of elementary school education if children are to gain a life-long interest in "the plant sciences.

Educational programs that emphasize hands on experiences with plants, like those at botanic gardens, 
have typically received little evaluation and commendation. Limited finding resources available for nonprofit institutions may be responsible for this omission. The objective of this research was to evaluate the impact of Missouri Botanical Garden's environmental education programs upon attitudinal and knowledge changes of elementary school children. It is hoped this data could be used to argue for additional plant science childhood education funding.

Two classes offered for second and third grade students at Missouri Botanical Garden were selected for evaluation. The first, "The Water Cycle: Making a Terrarium", describes the water cycle and requires students to construct and maintain a terrarium for at least one month. The second, "The Tropical Rainforest", describes characteristics of the tropical rainforest and requires students to propagate and subsequently plant stem cuttings of tropical species. Instructional methods of presentation varied for each class. Both classes utilized discussion and hands-on activities. The Water Cycle: Making a Terrarium class, however, incorporated video as an additional instructional medium. Primary school children comprising across section of the St. Louis area made a single, school sponsored visit to one or the other class. The two classes that the children attended were, for purposes of this study, evaluated as separate experiments.

Questionnaires were administered to students 7 to 10 days before and following participation in the classes. There were ten attitudinal questions, composed of two types. The first group, designed to evaluate attitudes toward interaction with plants and the environment, consisted of five questions. A sample question within this group was: "When I grow up I would like to work with plants." The second group of five questions was designed to evaluate attitudes toward learning about plants and the environment. A sample question within this group was: "I want to learn more about plants and the environment. " An additional five questions were designed to evaluate the children's knowledge base. Attitudinal questions were the same for both classes; knowledge questions differed depending on the material covered within classes.

Question content and vocabulary were reviewed for appropriateness by three elementary school teachers and a curriculum and instruction professional. Questionnaire validity was examined by an educational psychology professional. In addition, preliminary pilot studies were conducted to ensure that students understood questionnaire form and content. A teacher questionnaire was used to assess, in a qualitative sense, the overall impact of the classes upon students.

For both experiments, the treatment and control groups consisted of students who, respectively,. attended or did not attend classes from within the same schools. The treatment set in The Water Cycle: Making a Terrarium class included 35 males and $37 \mathrm{fe}-$ males; the control group consisted of 31 males and 40 females. The treatment set in The Tropical Rainforest class included 31 males and $31 \mathrm{fe}-$ males; the control group consisted of 33 males and 25 females.

Data collected from students in treatment and control groups were analyzed by subtracting pre-questionnaire means from post-questionnaire means. Responses which indicated a favorable attitude toward or correct knowledge of plants and the environment were scored as one, and other responses as zero. Data of this type cannot be assumed to fit a normal distribution and, therefore, treatment and control means were compared via the non-parametric Wilcoxon signed rank test (Hinkle et al., 1988).

Results indicate that neither of the classes had a significant effect upon male or female children's attitudes towards interacting with plants and the environment (Tables 1 and 2). This lack of effect maybe attributable to the novelty of the subject matter rather than to any inherent failure of the classes. It is likely that attitudes toward interaction would become more positive if students made repeated visits to the gardens. Recurrent field trips involving the same subject matter produce the best results in young children (Falk, 1983).

The Tropical Rainforest class had no effect upon student's attitudes towards learning about plants and the environment (Table 2). However, The Water Cycle: Making a Terrarium class did have a significant effect upon males $(P<0.05)$, females $(P<0.01)$, and the two sexes combined $[(P<0.01)$; Table 1]. The difference between classes with respect to attitudes toward learning may be related to subject matter and instructional methods. Some topics are more recognizable to children than others, and may have a stronger influence upon the development of attitudes (Armstrong and Impara, 1991). In addition, discussion and video are the two most preferred methods of instruction by students (Tamir, 1990).

Both classes had a highly significant effect $(P<0.01)$ on knowledge gain of males, females, and the sexes

Table 1. Effect of The Water Cycle: Making a Terrarium class on elementary school children's attitudes toward, and knowledgeabout, plants and the environment.

\begin{tabular}{|c|c|c|c|c|c|}
\hline Variable & Sex & Treatment & Mean & SD & $P$ \\
\hline \multirow[t]{6}{*}{ Attitudes toward interaction } & \multirow[t]{2}{*}{ Male } & Expt. & 0.29 & 1.07 & \\
\hline & & Control & -0.03 & 0.79 & NS \\
\hline & \multirow[t]{2}{*}{ Female } & Expt. & 0.38 & 0.98 & \\
\hline & & Control & 0.12 & 1.18 & NS \\
\hline & \multirow[t]{2}{*}{ Both Sexes } & Expt. & 0.33 & 1.02 & \\
\hline & & Control & 0.06 & 1.03 & NS \\
\hline \multirow[t]{6}{*}{ Atritudes toward learning } & \multirow[t]{2}{*}{ Male } & Expt. & 0.06 & 1.08 & \\
\hline & & Control & -0.68 & 1.35 & * \\
\hline & \multirow[t]{2}{*}{ Female } & Expt. & 0.32 & 0.94 & \\
\hline & & Control & -0.27 & 0.93 & * * \\
\hline & \multirow[t]{2}{*}{ Both sexes } & Expt. & 0.19 & 1.01 & \\
\hline & & Control & -0.45 & 1.14 & ** \\
\hline \multirow[t]{6}{*}{ Knowledge } & \multirow[t]{2}{*}{ Male } & Expt. & 1.62 & 1.26 & \\
\hline & & Control & 0.29 & 0.90 & ** \\
\hline & \multirow[t]{2}{*}{ Female } & Expt. & 1.72 & 1.48 & \\
\hline & & Control & -0.12 & 1.26 & ** \\
\hline & \multirow[t]{2}{*}{ Both sexes } & Expt. & 1.68 & 1.37 & \\
\hline & & Control & 0.05 & 1.13 & ** \\
\hline
\end{tabular}

$\mathrm{NS},{ }^{*},{ }^{* *}$ Nonsignificant or significant atP $=0.05$ or 0.01, respectively. 
Table 2. Effect of The Tropical Rainforest class on elementary school children's attitudes toward, and knowledge about, plants and the environment.

\begin{tabular}{|c|c|c|c|c|c|}
\hline Variable & Sex & Treatment & Mean & SD & $\boldsymbol{P}$ \\
\hline \multirow[t]{6}{*}{ Attitudes toward interaction } & Male & Expt. & 0.16 & 1.13 & \\
\hline & & Control & -0.15 & 1.35 & NS \\
\hline & Female & Expt. & 0.22 & 0.92 & \\
\hline & & Control & 0.20 & 1.22 & NS \\
\hline & Both sexes & Expt. & 0.19 & 1.01 & \\
\hline & & Control & 0.00 & 1.30 & NS \\
\hline \multirow[t]{6}{*}{ Attitudes toward learning } & Male & Expt. & 0.03 & 1.35 & \\
\hline & & Control & 0.18 & 1.51 & NS \\
\hline & Female & Expt & -0.06 & 1.42 & \\
\hline & & Control & 0.56 & 1.12 & NS \\
\hline & Both sexes & Expt. & -0.01 & 1.42 & \\
\hline & & Control & 0.34 & 1.35 & NS \\
\hline \multirow[t]{6}{*}{ Knowledge } & Male & Expt. & 1.13 & 1.28 & \\
\hline & & Control & -0.03 & 1.28 & ** \\
\hline & Female & Expt. & 1.03 & 1.30 & \\
\hline & & Control & -0.12 & 1.33 & ** \\
\hline & Both sexes & Expt. & 1.10 & 1.28 & \\
\hline & & Control & -0.07 & 1.29 & ** \\
\hline
\end{tabular}

NS, ${ }^{*},{ }^{* *}$ Nonsignificant or significant at $P=0.05$ or 0.01 , Respectively.

combined (Tables 1 and 2). Research suggests that, per unit time, children learn more in nonformal settings than in traditional classrooms. To obtain maximum benefit from field trips the physical setting of activities must be directly relevant to the subject matter covered (Falk,1983).

Comparisons of male and female students in both classes yielded no difference between the sexes in their attitudes toward interaction with, or learning about, the environment. In addition, results indicate no difference in knowledge gained between male and female.

Questionnaires received from the children's elementary school teachers revealed that classes at Missouri Botanical Garden were considered to be educational for students. Post-trip activities included discussion of the children's experience, along with continued observation of plants and terrariums received at the garden. Teachers noted that children responded most favorably to the participatory activities in which they were involved, and following class participation that children's level of awareness concerning plants and the environment increased.
It is evident that field trip activities of this type can influence the development of children's attitudes and increase the acquisition of knowledge. Such programs have the potential to instill a horticulture awareness in children that may eventually influence choice of college studies, career decisions, and recreational activities. Further research is needed to determine how to maximize the effectiveness of this type of experience, and horticultural educators should be encouraged to conduct additional studies. The challenge is to develop appropriate curricula for nonformal settings that will have a positive horticultural influence on young children.

\section{Literature Cited}

Armstrong, J . and J . Impara. 1991. The impact of an environmental education program on knowledge and attitude. J. Environ. Educ. 22(4):36-40.

Booth, J ., G. Krockover, and P. Woods. 1982. Creative museum methods and educational techniques. Charles C. Thomas Publ., Springfield, III.

Christmas, O. 1990. Why enroll? Student enrollment strategy in the college of agriculture. ERIC document 314608:89.
Couvillon, G. 1991. Graduate and undergraduate horticultural enrollment and programs in U.S. institutions. HortScience 26:472-474.

Danilov, V. 1976. Museums as educational partners. Childhood Educ. 52(6):306-311.

Falk, . 1983. Field trips: A look at environmental effects on learning. J. Biol. Educ. 17(2):137-142.

Gwynn, D. and O. Thompson. 1990. Agriculture schools must broaden their curricula to attract new groups of students. Chronicle of Higher Educ. 37(14): B2-3.

Hinkle, D., W. Wiersma, and S. J urs. 1988. Applied statistics for the behavioral sciences. Houghton Mifflin Co., Boston.

Inhelder, B. 1970. Some aspects of Piaget's genetic approach to cognition, cognitive development in children. Soc. Res. Child Development. Univ. of Chicago Press.

J ackson, G. 1992. Laboratory instruction in an urban horticulture program. Agr. Educ. Msg. 64(10):16-18.

J aus, H. 1984. The development and retention of environmental attitudes in elementary school children. J . Environ. Educ. 15(3):33-36.

Klepper, N. 1990. Lifetime legacy: the successful field trip. Amer. Biol. Teacher 52(4):245-248.

Linsky, R. 1971. Educational strategies for an environmental ethic. Sci. Teacher 38(1):16-18.

Matthai, R. and N. Deaver. 1976. Child centered learning. Museum News 54(4):15-19.

Pitman-Gelles, B. 1981. Museums, magic and children. Assn. Sci. Technol. Ctr., Washington, D.C.

Smith, H. and T. Nagel. 1972. Instructional media in the learning process. Merrill Publ., Columbus, Ohio.

Tamir, P. 1990. Factors associated with the relationship between formal, informal, and nonformal science learning. J. Environ. Educ. 22(2):34-42.

Tourney, J . and C. Tesconi. 1977. Political socialization research and respect for ethnic diversity. Praeger Publ., New York.

Whittlin, A. 1970. Museums, in search of a usable future. M. I .T. Press, Cambridge, Mass. 